УДК: 72.033 .5

ББК: 85.11

A43

DOI: $10.18688 /$ aa $199-4-47$

G. Pollini

\title{
At the Borders of the Regnum of Naples. The Guglia and the Princes of Taranto Orsini del Balzo in Soleto ${ }^{*}$
}

Founded in Norman times, the Principality of Taranto had a centuries-old history as a state in the South-East of Italian peninsula. The Principality, named after its capital Taranto in Apulia, was a satellite area at the borders of various kingdoms of the Mezzogiorno ${ }^{2}$. Passing to the Normans, Swabians and then to the Angevins, the Principality was bound to the central power, and its Princes were chosen among the ruling families ${ }^{3}$. In this way, the Reign could benefit from the natural geographical strategy of this domain, especially for trade with the Adriatic Sea and the East ${ }^{4}$. Above all for the Angevins, the territory was indeed a political, institutional and financial vehicle to pursue broader intents [3, p. 23].

An exception to this long series of rulers was the Orsini del Balzo family ${ }^{5}$, the first house not strictly related to the royal one, represented by Raimondo (1350/1355-1406) [50] and his son Giovanni Antonio (1401-1463) [27]. Their government began in 1399 and ended in 1463, and it was interrupted between 1407 and 1420, when the Principality returned to the hands of the King Ladislao Durazzo (1377-1414) [9, p. 81], thanks to his marriage with Maria d'Enghien (1367-1446), widow of Raimondo [16]. The rule of the Orsini del Balzo was focused on an administrative, judicial and tax organisation of an increasingly vast fiefdom [34, p. 128], and the power acquired allowed them to adopt separatist tendencies from the Crown ${ }^{6}$.

The Orsini del Balzo established a permanent court in their Apulian borders, giving new primacy to the County of Soleto, in the core of Salento [26, pp. 58-59; 54, p. 191]. This area was chosen by its geographical position: cities as Soleto and Galatina could connect important

\footnotetext{
$1 \quad *$ I would like to thank the Ufficio Diocesano per l'Arte Sacra e i Beni Culturali dell'Arcidiocesi di Otranto and Fra Rocco Cagnazzo for the permission to publish picture Fig. 5, representing a particular of the Giovanni Antonio Orsini del Balzo's cenotaph in St. Caterina d'Alessandria in Galatina. I am really grateful to prof. Luigi Cerfeda, Don Antonio Santoro and Luigi Manni for their help during my research.

2 A brief overview of the Principality of Taranto through the centuries, from its foundation to its end, is given by [9]. see $[1 ; 23]$.

For the historical context and for a wide and general knowledge of the art under the Angevin domain

$4 \quad$ There are many studies about trades established by the Principality and the Reign of Naples with the Adriatic coast and the East, as it is possible to see in [38; 42].

$5 \quad$ One of the most important and recent publications about the Orsini del Balzo family is [10].

6 About the autonomy of the Orsini del Balzo's Principality, there is an open discussion, efficaciously faced by [51].
} 


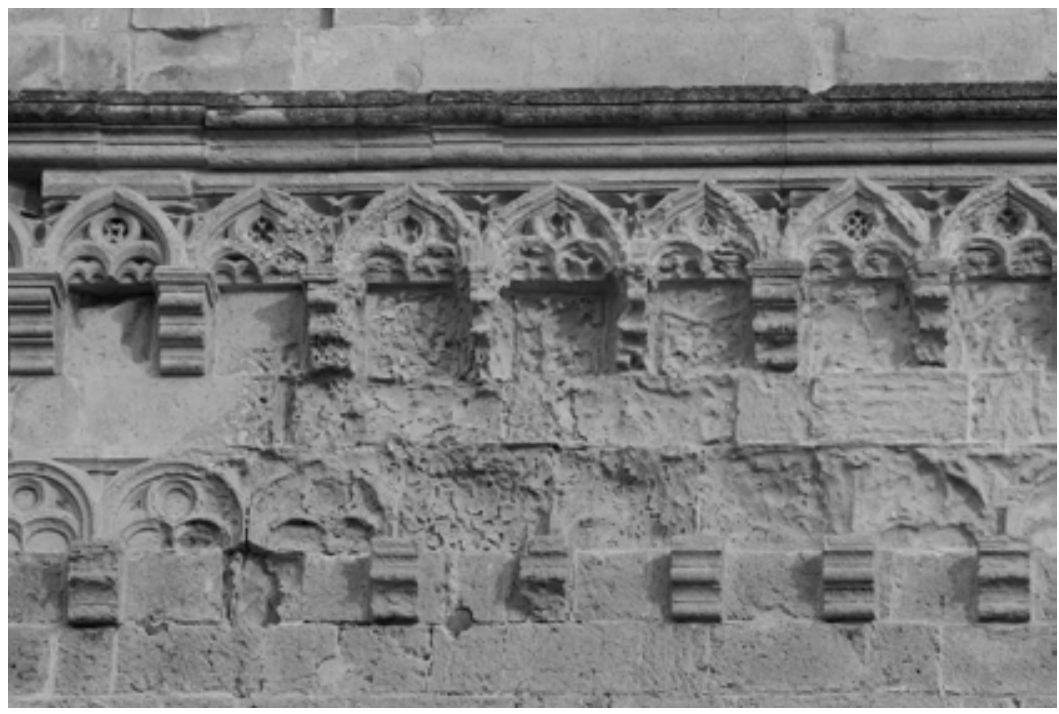

Fig. 1. Decoration with arches, second story, west side, Guglia. $15^{\text {th }}$ century. Soleto. Photo by G. Pollini

centres as Lecce to strategic coast villages, such as Otranto, Gallipoli, and Nardò, along with the main commercial routes of the region ${ }^{7}$. So right here, in this County, the glories of the house are celebrated by several monuments.

For example, in Galatina, in the 1380s Raimondo founded the famous basilica of St. Caterina d'Alessandria, which was entrusted with its monastery to Observant Franciscan Order of Bosnia in $1391^{8}$. In the first half of the $15^{\text {th }}$ century the church was covered with astonishing frescoes $[15$, p. 11] and was furnished with two funeral monuments dedicated one to Raimondo in the presbytery, and the other to Giovanni Antonio ${ }^{9}$ in the octagonal choir added to the apse by the same younger Orsini del Balzo between 1450 and 1460 [31, p. 42].

Also, Soleto can offer a few shreds of evidence of Princes' patronage. From the small church of S. Stefano, with its extraordinary layers of frescoes, painted in the end of the $14^{\text {th }}$ century [ 36 , pp. 73-130], to the extra moenia church of St. Lucia, today destroyed and chronicled only by documents and drawings of the end of the $19^{\text {th }}$ century [44, p. 568]. However, the piece of art that mainly displays this domination is undoubtedly the so-called Guglia, a square tower, approximately $45 \mathrm{~m}$ tall, culminating in an octagon, decorated with sculptures and coats of arms, attested as a belfry of the Church of Maria Santissima Assunta in the $16^{\text {th }}$ century $^{10}$ (Ill. 98).

\footnotetext{
$7 \quad$ For the territorial extension of the Principality under the Orsini del Balzo see [13].

8 The story of the foundation of St. Caterina d'Alessandria in Galatina can be recalled thanks to [43].

$9 \quad$ For more information about the two funeral monuments see my research La memoria dei principi di Taranto in S. Caterina a Galatina. Studi preliminari sui monumenti funebri di Raimondo e Giovanni Antonio Orsini del Balzo presented at the conference In corso d'opera 3 organised by Sapienza University of Rome (forthcoming). 10 As it is written in the pastoral visitation of mons. Fabrizio De Capua, in 1538-1540, the church "Habet duo campanilia: unum solemne ac magno cum duabus campanis magnis et aliud parvum cum duabus parvis campanis". The big bell tower of the text can be referred to the Guglia (Archivio Diocesano Otranto, fondo Curia arcivescovile, sez. I, serie Atti visitali, u.a. 1, Visita pastorale di mons. Fabrizio De Capua, 1538-1540, tomo I). About the church of Maria Santissima Assunta see [47].
} 


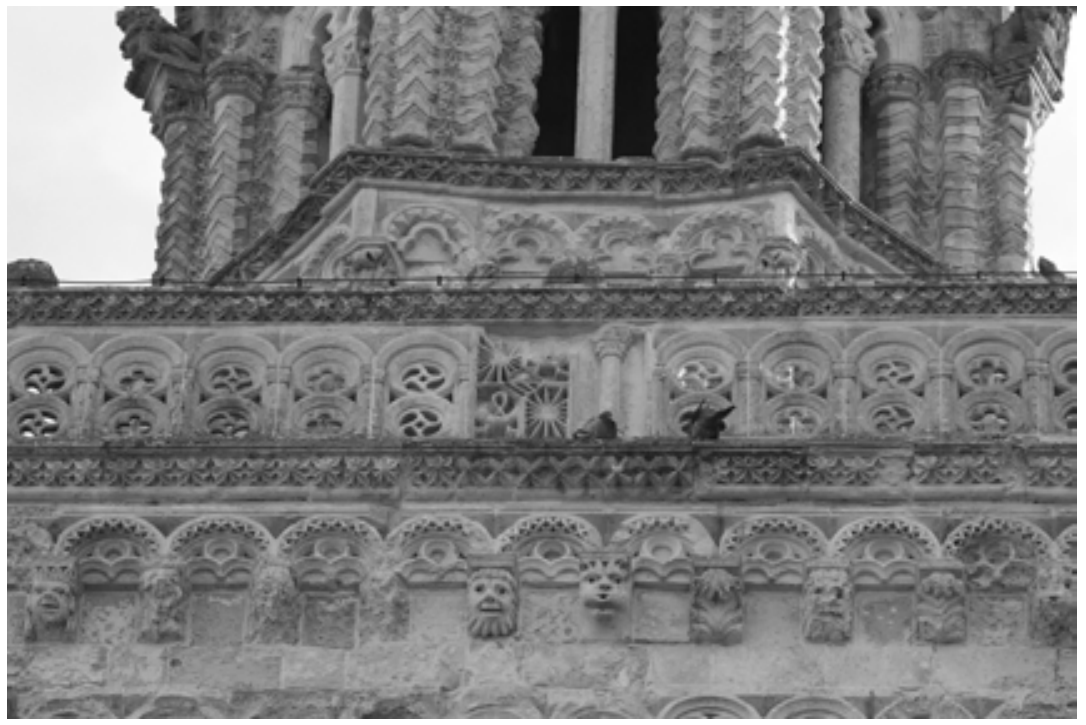

Fig. 2. Insignia of Orsini del Balzo and Colonna, balustrade, west side, Guglia. $15^{\text {th }}$ century. Soleto. Photo by G. Pollini

The monument is composed of five levels slightly tapered in tufo carparo and incorporates a cylindrical tower that reaches up to the second floor, with its axis shifted towards the North and a spiral staircase interrupted [5, p. $77 ; 18$, p. $58 ; 29$, p. $25 ; 45$ p. $41 ; 53$, p. 56]. The first two stories do not have windows and are decorated with a series of trefoil and arches on corbels (Fig. 1). Until the beginning of the $20^{\text {th }}$ century, on the north side of the first floor it was possible to see some frescoes [18, pp. 58-59;29, pp. 25-26], once inside an atrium in front of the entrance to the church, as it is noticeable in a sketch by Jean Desprez, drawn between 1777 and 1779, and then modified for the Voyage pittoresque by Richard de Saint-Non [20, pp. 57-58; 21, figs 38, 114]. The third and fourth levels, on the other hand, have a rich decoration: on each side, there is a mullioned splayed window with a depressed arch in a square frame, embellished by twisted and zigzag columns, a diamond points decoration and phytomorphic capitals supporting a heart-shaped motif between trefoil arches. All the mullioned windows are joined together by two frames that surround the tower, one smooth and one covered with leaves, and they are protected by pairs of lions, eagles, and gryphons (Ill. 97). The latter beasts, provided with crowns, are also placed at the corners of the two floors. The decoration is completed by a double row of trefoil arches on corbels with human faces, animals and leaves. In the end, the top story has an octagonal shape, and its decoration is similar to the lower floors, but with double-pointed mullioned windows. The octagon is then covered by a spherical dome and surrounded by a balustrade where the Orsini del Balzo coat of arms is carved three times: alone on the east side (Ill. 99), with the emblem of Maria d'Enghien-Brienne, wife of Raimondo, on the north side, and with the insignia of Anna Colonna, spouse of Giovanni Antonio, on the west one (Fig. 2). 


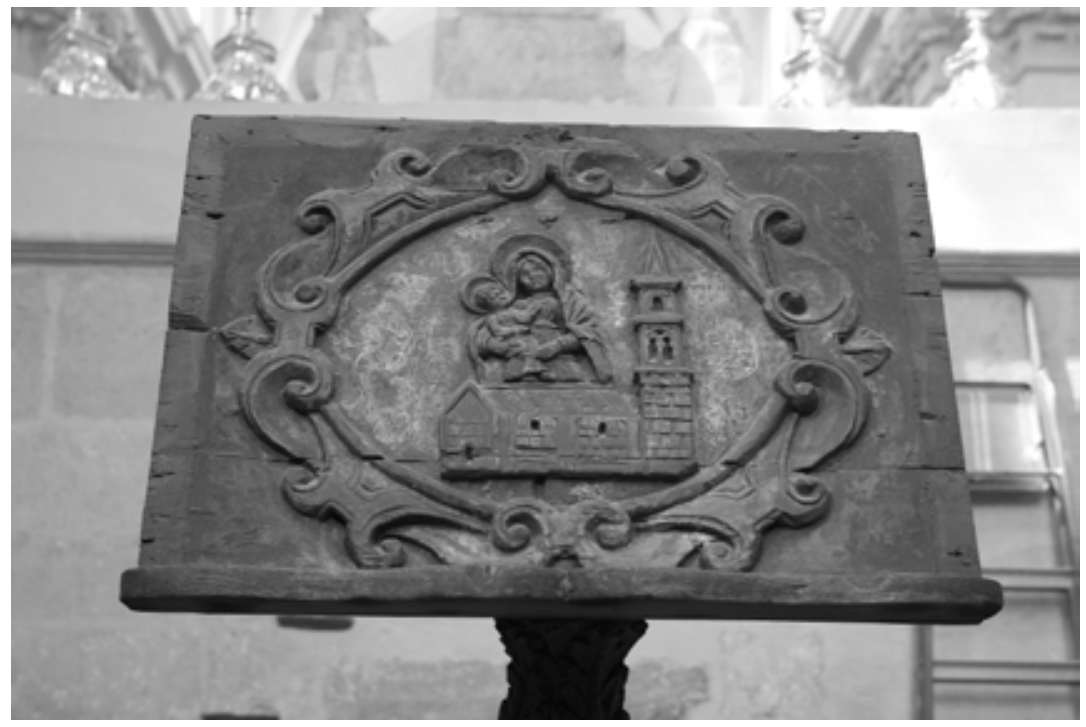

Fig. 3. Lectern. 1624. Maria SS.ma Assunta, Soleto.

Photo by G. Pollini

The current appearance of the Guglia is the result of several restorations, the most important of which was that of $1750^{11}$, when the numerous parts ruined by a lightning were replaced, new sculptures were created similar to the existing ones, and a big portion of the balustrade was rebuilt $[11 ; 53$, p. 58]. It is perhaps on this occasion, that the Orsini del Balzo's emblem was turned upside down. Moreover, that year a spherical dome was erected to replace the original one which was pyramidal, as it is shown on a bas-relief sculpted on a lectern of 1624 in the church of Maria SS.ma Assunta (Fig. 3).

The precise time of the erection of the monument is still discussed, although it may be certainly linked to the Orsini del Balzo, thanks to their coats of arms. Even though not so many years passed between the governments of Raimondo and Giovanni Antonio, their patronages were really dissimilar. The first was more devoted to the tradition of Romanesque art: the basilica of St. Caterina in Galatina lingers on a local language, as happens right in the façade of the church or in the central nave's capitals [28, pp. 187-190]. Instead, the second preferred the International Gothic current to what was happening in the Regnum and the Adriatic coasts, as it is attested by his funeral monument ${ }^{12}$. In light of this difference, finding who commissioned the belfry is quite essential to relate it with a distinctive cultural atmosphere.

The critics have presented three datings. The majority of them believe that the Guglia had been commissioned by Raimondo to the architect Francesco Colaci from Surbo (a little town near Soleto) in 1397, as was declared on a slab in the fourth order of the tower, already missing 


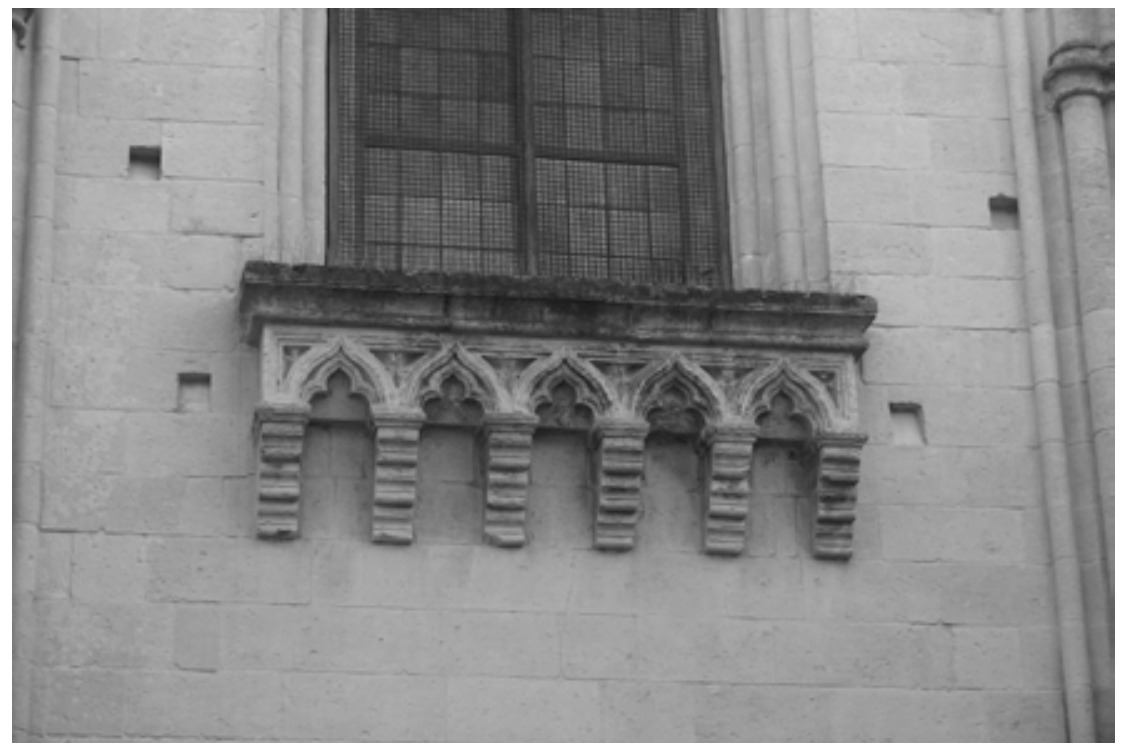

Fig. 4. Decoration with arches. $15^{\text {th }}$ century. Choir of St. Caterina d'Alessandria, Galatina. Photo by G. Pollini

at the end of the $19^{\text {th }}$ century ${ }^{13}[4$, p. $561 ; 7$, p. $721 ; 17$, pp. $303-304 ; 18$, p. $57 ; 22$, pp. $68-69$; 25 , p. $82 ; 30$, p. $202 ; 39$, p. $10 ; 53$, pp. 49-52]. The scholars, certain of the existence of this lost inscription, report the information given by a poet of Surbo, Vincenzo Ampolo, to Cosimo de Giorgi, who wrote it down in 1903 [17, pp. 303-304]. Ampolo said to his friend that this slab, which was copied and disappeared at an uncertain time, was found during the episcopate of Monsignor Alfonso Sozi-Carafa (1752-1783), after a thunderstorm that damaged the tower. Actually, this attestation has been verified as false and the slab, never seen or published by scholars who merely ascertain its destruction, is probably invented. If it existed, then, it should be traced in the documents of the restoration of 1750, which took place a few years before the presumed discovery. The information was instead the result of a union of different news. According to the Critica Propositio of 1774 written by the theologian Stanislao a Sancto Paolo, the date of 1397 had to appear not on the tower, but was engraved on a column inside the ancient church of Maria SS.ma Assunta, demolished and rebuilt by 1783 [48, pp. 21-22]. Moreover, the name of Francesco Colaci seems to have been transmitted without any evidence by the poet from Surbo, who probably wanted to give prestige to his village by linking one of his ancient countrymen to the famous monument [12, p. 272, footnote 52].

Alongside the critics who are convinced in the authorship of Francesco Colaci and the patronage of Raimondo, a second group of scholars, who do not reject the architect from Surbo as the author of the Guglia, believes that the building was started under Raimondo and finished under Giovanni Antonio, several years after 1397 [2, p. 131; 8, p. 20; 19, p. 23; 24 , pp. $12-13$; 29, pp. 25-26; 33, p. 66; 40, pp. 64, 67; 41, p. 126; 45, p. 42]. The motivation is 


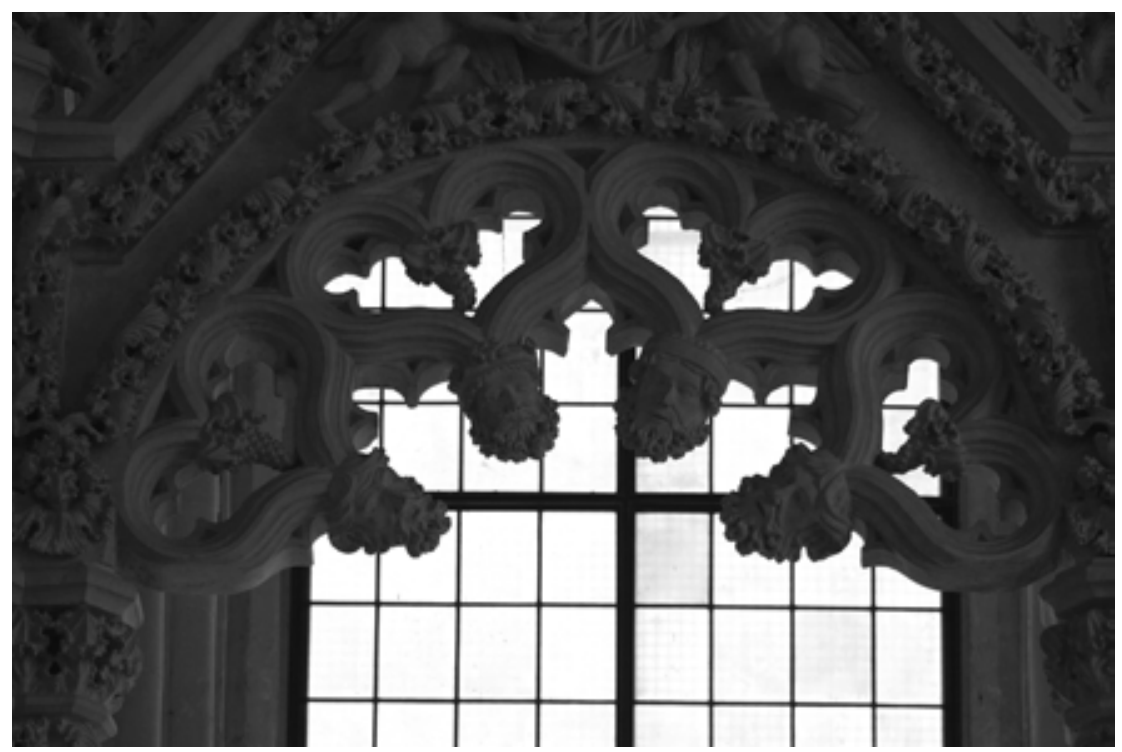

Fig. 5. Decoration of the cenotaph of Giovanni Antonio Orsini del Balzo. $15^{\text {th }}$ century. Choir of St. Caterina d'Alessandria, Galatina. Photo by G. Pollini. (c) Ufficio Diocesano per l'Arte Sacra e i Beni Culturali dell'Arcidiocesi di Otranto

represented by the Orsini del Balzo emblem sculpted together with that of Anna Colonna, in memory of the marriage between the younger Prince and the niece of Pope Martino $\mathrm{V}$ (1368-1431) in 1425 [32, p. 221]. Very few other academics, however, consider the tower to be built right in the first half of the $15^{\text {th }}$ century [5, p. 75; 12, p. 272; 49, p. 73; 52, p. 12 footnote 2], a hypothesis that this paper wants to endorse through the following considerations.

The architecture of the Guglia, made of a square base with octagon and pyramidal roof, reflects a taste already attested in the late $14^{\text {th }}$ century in Apulia and continued in the following decades. This is testified by the $13^{\text {th }}$-century bell tower of the cathedral in Trani, to which an octagon was added between 1352 and 1379 [46, pp. 65-66], or the Romanesque belfry of the cathedral in Andria, completed with the last polygonal story in the second half of the $15^{\text {th }}$ century $[35$, p. 122]. However, the tower of Soleto is a unicum in the whole region for its dense decoration, which makes it more similar to a golden object ${ }^{14}$, combining a traditional language, with anthropomorphic faces and a bestiary made of stone, with a fully $15^{\text {th }}$-century ornamental taste [37, p. 462]. In particular, it is possible to find strong similarities with the aforementioned choir of St. Caterina in Galatina, whose construction was paid by Giovanni Antonio in 1459 [31, p. 42]. In fact, the corbels supporting the trefoil arches of the tower and those of the outside of the Franciscan chapel can be overlapped, thanks to torus mouldings alternating with scotias, placed one above the other, and a cloverleaf decoration in the triangular spaces between the arches (Fig. 4). Furthermore, the join of tortile and zig-zag columns in the belfry can be found in the incomplete pillars of the Orsini del Balzo's funerary octagon, and the heart-shaped motif of the mullioned windows finds a parallel in the cenotaph of Giovanni 
Antonio, coeval with the choir and probably made by Dalmatian sculptors ${ }^{15}$ (Fig. 5). Finally, the shape of the mullioned windows, composed by depressed arches within square frames, seems to suggest an early knowledge of the motif of Durazzesque portals in Naples [2, p. 132], of which Palazzo Penne is the first successful example [14].

In this way, the Guglia is characterised by a language that is receptive to the already mentioned International Gothic and fits well into the patronage of Giovanni Antonio, thanks to the continuous connections with his choir and funeral monument in Galatina, and also to the attention paid to the artistic novelties of the Kingdom.

Beyond these correspondences, the clear political message of this tower can support the patronage of the young Prince. The Guglia is located in the centre of the County of Soleto and on the geographically highest point of the fiefdom ( $90 \mathrm{~m}$ above sea level), so it can proclaim the power of the Orsini del Balzo to neighbouring countries. Specifically, it is built near the southwest walls of the city, right in front of the road that still leads to Galatina and its basilica. It is manifest that the two monuments are connected by artistic and geographical links, and, above all, by an ideological bound. It does not seem a coincidence that the tower is protected by the same animals guarding the façade of the Franciscan church, which are lions and eagles, and that these beasts are joined together in the gryphons of Soleto. If these references to St. Caterina in Galatina and its sculptures may propose that the Guglia could be erected by Raimondo and then finished by Giovanni Antonio after 1425, a reflection on the selection of insignias on the tower may suggest that the work was conceived by the young Prince as a political propaganda instrument. As has been noted earlier, these emblems represent the matrimonial ties of the Orsini del Balzo with Enghien-Brienne and Colonna, which are also sculpted several times on the outer faces of the octagonal choir in Galatina. At first, on both monuments this choice appears to be the most obvious because it demonstates the origins and alliances of the Princes. But, if we consider the heraldry that appears inside St. Caterina d'Alessandria, then a discrepancy emerges. In the church of Galatina, in fact, between the crests of the family, a different marriage bond stands out, the one between Maria d'Enghien and Ladislao Durazzo, painted several times on the walls and placed in the centre of the stained-glass rose window of the façade [15, p. 54]. This coat of arms was used by Raimondo's widow, also after her second husband's death (1414), for the sake of convenience, to keep her title of Queen once returned in Apulia. Considering the important role played by this symbol in the basilica, its absence both in the choir and on the Guglia is certainly symptomatic: besides being a possible clue of the death of Maria ( $\dagger 1446$ ), this becomes a strong declaration of power. It is as if Giovanni Antonio wanted to erase part of the dynastic succession in the Principality to make it solely linked to the events of his real household. He did not need to show his connection with the King to maintain what was due to himself by fatherly law. Moreover, the crowns on the four statues of the gryphons on the second level of the Guglia seem to be a declaration of independence of Orsini del Balzo on the County, the only ones who have the right to govern this territory at the borders of the Kingdom.

15 As already written, see my research La memoria dei principi di Taranto in S. Caterina a Galatina. Studi preliminari sui monumenti funebri di Raimondo e Giovanni Antonio Orsini del Balzo (in print). 


\section{References}

1. Abbate F. Storia dell'arte nell'Italia Meridionale. Il Sud angioino e aragonese. Roma, Donzelli Publ., 1998. 273 p. (in Italian).

2. Agnello G. L'architettura aragonese-catalana in Italia. Palermo, Chicca Publ., 1969. 166 p. (in Italian).

3. Alaggio R. Il ruolo dei principi di Taranto nelle vicende del Regno di Napoli. Dal Giglio all'Orso. I Principi d'Angiò e Orsini del Balzo nel Salento. Galatina, Congedo Publ., 2006, pp. 117-133 (in Italian).

4. Arditi G. La corografia fisica e storica della provincia di Terra d'Otranto. Lecce, Scipione Ammirato Publ., 1879. 652 p. (in Italian).

5. Bernich E. L'Arte in Puglia. Il campanile di Soleto. Napoli Nobilissima, 1902, vol. 11, 5, pp. 75-79 (in Italian).

6. Boraccesi G. Oreficeria sacra in Puglia. Tra Medioevo e Rinascimento. Foggia, Grenzi Publ., 2005. 128 p. (in Italian).

7. Calò Mariani M. S. Dal Chiostro alle corti. Storia di Lecce dai Bizantini agli Aragonesi. Roma; Bari, Laterza Publ., 1993, pp. 661-732 (in Italian).

8. Canali F.; Galati V. Architetture e ornamentazioni dalla Toscana al Lazio, agli 'umanesimi baronali' del Regno di Napoli (1430-1510) (I). Bollettino della Società di Studi Fiorentini, 1999, vol. 5, pp. 9-39 (in Italian).

9. Carducci G. Il Principato di Taranto. Osservazioni critiche ed annotazioni bibliografiche. Cenacolo, 2000, vol. 12, pp. 59-90 (in Italian).

10. Cassiano A.; Vetere B. (eds.). Dal Giglio all'Orso. I Principi d’Angiò e Orsini del Balzo nel Salento. Galatina, Congedo Publ., 2006. 482 p. (in Italian).

11. Cazzato M. Note di archivio. Lavori settecenteschi alla guglia di Soleto. Voce del Sud, 1983, May $14^{\text {th }}$, p. 5 (in Italian).

12. Cazzato M. Larea galatinese: storia e geografia delle manifestazioni artistiche. Dinamiche storiche di unarea del Salento. Galatina, C.R.S.E.C. Publ., 1989, pp. 261-346 (in Italian).

13. Cengarle F.; Somaini F. Mappe informatiche e storia. Considerazioni metodologiche e prime ipotesi cartografiche sui domini orsiniani. Geografie e linguaggi politici alla fine del Medioevo. I domini del principe di Taranto in età orsiniana (1399-1463). Galatina, Congedo Publ., 2009, pp. 3-35 (in Italian).

14. Cuccaro A. Palazzo Penne e l'edilizia residenziale in età durazzesca a Napoli. Universitates e Baronie. Arte e architettura in Abruzzo e nel Regno al tempo dei Durazzo. Atti del convegno, (Guardiagrele-Chieti), 9-11 novembre 2006, vol. 2. Pescara, ZIP Publ., 2008, pp. 119-137 (in Italian).

15. Cucciniello A. Galatina, basilica di Santa Caterina d'Alessandria. Dagli intendimenti ammirata. La decorazione pittorica. Pittura tardogotica nel Salento. Galatina, Congedo Publ., 2014, pp. 3-72 (in Italian).

16. Cutolo A. Maria d'Enghien, Regina di Napoli. Galatina, Congedo Publ., 1977. 201 p. (in Italian).

17. De Giorgi C. La Chiesa di S. Caterina in Galatina e la torre quadrata di Soleto. Rivista storica Salentina, 1903, vol. 1, pp. 286-307 (in Italian).

18. De Giorgi C. La Provincia di Lecce. Bozzetti di viaggio, vol. 2. Lecce, Congedo Publ., 1975. 438 p. (in Italian).

19. De Marco M. Soleto. La chiesetta di S. Stefano e la "guglia" di Raimondello. Rassegna salentina, 1978, vol. 3, pp. 5-25 (in Italian).

20. De Saint-Non S. C. R. Voyage pittoresque à Naples et en Sicile, vol. 3. Paris, Clousier Publ., 1783. 410 p. (in French).

21. Fiorino F. Viaggiatori francesi in Puglia dal Quattrocento al Settecento. Fasano, Schena Publ., 1993. 558 p. (in Italian).

22. Foscarini A. Arte e Artisti di Terra d'Otranto tra medioevo ed età moderna. Manduria, Edizioni del Grifo Publ., 2000. 277 p. (in Italian).

23. Galasso G. Il Mezzogiorno angioino e aragonese (1266-1494). Torino, Utet Publ., 1992. 919 p. (in Italian).

24. Gelao C. Puglia rinascimentale. Milano, Edipuglia Publ., 2005. 318 p. (in Italian).

25. Gigli G. Il Tallone d'Italia. Lecce e dintorni, vol. 1. Bergamo, Istituto Italiano d'Arti Grafiche Publ., 1911. 128 p. (in Italian).

26. Kiesewetter A. Problemi della signoria di Raimondo del Balzo Orsini in Puglia (1385-1406). Dal Giglio all'Orso. I Principi d’Angiò e Orsini del Balzo nel Salento. Galatina, Congedo Publ., 2006, pp. 37-89 (in Italian). 
27. Kiesewetter A. s.v. Orsini Del Balzo, Giovanni Antonio. Dizionario Biografico degli Italiani, vol. 79. Catanzaro, Istituto dell'Enciclopedia Italiana Publ., 2013, pp. 729-732 (in Italian).

28. Kemper D. SS. Niccolò e Cataldo in Lecce als ein Ausgangspunkt für die Entwicklung mittelalterlicher Bauplastik in Apulien und der Basilicata. Worms, Warner Publ., 1994. 240 p. (in German).

29. Manni L. La chiesa di Maria SS.ma Assunta di Soleto. Maria SS.ma Assunta Soleto. La Chiesa. Il Santo Patrono. La Storia. Il Restauro. Galatina, Editrice Salentina Publ., 2011, pp. 13-100 (in Italian).

30. Marti P. Ruderi e monumenti nella Penisola Salentina. Lecce, La modernissima Publ., 1932. 249 p. (in Italian).

31. Massaro C. Potere politico e comunità locali nella Puglia tardomedievale. Galatina, Congedo Publ., 2004. 185 p. (in Italian).

32. Massaro C. Anna Colonna principessa di Taranto. Spazi e pratiche di potere. Geografie e linguaggi politici alla fine del Medioevo. I domini del principe di Taranto in età orsiniana (1399-1463). Galatina, Congedo Publ. 2009, pp. 213-238 (in Italian).

33. Montinari M. Soleto. Una città della Grecia Salentina. Fasano, Schena Publ., 1993. 235 p. (in Italian).

34. Morelli S. "Pare'l pigli tropo la briglia cum li denti": dinamiche politiche e organizzazione del Principato di Taranto sotto il dominio di Giovanni Antonio Orsini. Geografie e linguaggi politici alla fine del Medioevo. I domini del principe di Taranto in età orsiniana (1399-1463). Galatina, Congedo Publ., 2009, pp. 127-163 (in Italian).

35. Morgigni M. Pagine sparse nella storia civile e religiosa di Andria. Andria, Bonaventura Terlizzi Publ., 1919. 214 p. (in Italian).

36. Ortese S. Pittura tardogotica nel Salento. Galatina, Congedo Publ., 2014. 324 p. (in Italian).

37. Pace V. Apulien, Basilicata, Kalabrien. Darmstadt, Wiss. Buchges. Publ., 1994. 496 p. (in German).

38. Palumbo P. F. Per una storia delle relazioni tra le due sponde Adriatiche. Bari, Società di Storia Patria per la Puglia Publ., 1962. 109 p. (in Italian).

39. Panico G. Allombra del campanile di Soleto. Galatina, Mariano Publ., 1910. 15 p. (in Italian).

40. Paone M. Arte e cultura alla corte di Giovanni Antonio del Balzo Orsini. Studi di storia pugliese in onore di Giuseppe Chiarelli, vol. 2. Galatina, Congedo Publ., 1973, pp. 59-101 (in Italian).

41. Petrucci A. Cattedrali di Puglia. Roma, Bestetti Publ., 1976. 219 p. (in Italian).

42. Popovic-Radenkovic M. Le relazioni commerciali fra Dubrovnik (Ragusa) e la Puglia nel periodo angioino (1266-1442). Archivio Storico per le Province Napoletane, 1958, vol. 37, pp. 73-104, 1959; vol. 38, pp. 154-206 (in Italian).

43. Poso C. D. La fondazione di Santa Caterina: scelta devozionale e committenza artistica di Raimondo Orsini del Balzo. Dal Giglio all'Orso. I Principi d’Angiò e Orsini del Balzo nel Salento. Galatina, Congedo Publ., 2006, pp. 195-223 (in Italian).

44. Poso R. Distruzione e tutela a Soleto. Studi in onore di Michele D’Elia. Matera, R\&R Publ., 1996, pp. 567-576 (in Italian).

45. Rizzo T. Un centro minore del Salento: Soleto. Parametro, 1989, vol. 170, pp. 16-43 (in Italian).

46. Ronchi B. La cattedrale di Trani. Fasano, Schena Publ., 1985. 302 p. (in Italian).

47. Rossetti P. (ed.). Maria SS.ma Assunta Soleto. La Chiesa. Il Santo Patrono. La Storia. Il Restauro. Galatina, Editrice Salentina Publ., 2011. 347 p. (in Italian).

48. Stanislaus a Sancto Paulo. Critica Propositio. Lecce, Ex Officina Viveritiana Publ., 1774 (in Latin).

49. Toesca P. Il Trecento. Torino, UTET Publ., 1951. 979 p. (in Italian).

50. Toomaspoeg K. s. v. Orsini Del Balzo, Raimondo. Dizionario Biografico degli Italiani, vol. 79. Catanzaro, Istituto dell'Enciclopedia Italiana Publ., 2013, pp. 732-735 (in Italian).

51. Vallone G. Le terre orsiniane e la costituzione medievale delle terre. Un principato territoriale nel Regno di Napoli? Gli Orsini del Balzo principi di Taranto (1399-1463). Roma, ISIME Publ., 2013, pp. 247-334 (in Italian).

52. Venturi A. Storia dellarte italiana. Larchitettura del Quattrocento, vol. 8.2. Milano, Hoepli Publ., 1924. 818 p. (in Italian).

53. Zacchino V. La guglia di Raimondo del Balzo Orsini. Paesi e figure del vecchio Salento. Galatina, Congedo Publ., 1980, pp. 49-58 (in Italian).

54. Zacchino V. In umbilico totius peninsulae. Galatina e dintorni dai Bizantini ai Napoleonidi. Dinamiche storiche di uniarea del Salento. Galatina, C.R.S.E.C. Publ., 1989, pp. 131-240 (in Italian).

Title. At the Borders of the Regnum of Naples. The Guglia and the Princes of Taranto Orsini del Balzo in Soleto. 
Author. Giulia Pollini — Ph. D. student. Sapienza University of Rome, Piazzale Aldo Moro 5, 00185 Rome, Italy.giulia.pollini@uniroma1.it

Abstract. Founded in Norman times, the Principality of Taranto was a satellite area at the borders of various kingdoms, passing to Swabians and Angevins. Under the governor of the central power, its Princes were chosen among the ruling families to control the territory better and take advantage of its natural geographical strategy, especially for trade with the Adriatic Sea and the East. The exception to this long series of rulers was the Orsini del Balzo family, with its two representatives Raimondo ( $\dagger 1406)$ and his son Giovanni Antonio $(\dagger 1463)$, totally focused on making the fief firmer thanks to some separatist tendencies from the Crown. After the election of Raimondo Orsini del Balzo as Prince of Taranto in 1399, many artistic centres flourished in small towns. An example is the magnificent basilica of S. Caterina in Galatina (near Lecce) founded by Raimondo, which houses Princes' tombs and well-known frescoes of the beginning of the $15^{\text {th }}$ century.

A few kilometres away from Galatina, the small town of Soleto was invested with new importance by the Orsini del Balzo. The core of the homonymous County, it reached its maximum territorial expansion during that time. Here there are several sites celebrating the glories of the family, but the most important one is the so-called Guglia, a belfry, approximately $45 \mathrm{~m}$ tall, decorated with sculptures and coats of arms, leant against the façade of the Church of Maria Santissima Assunta. The paper is focused on the analysis of this monument, variously dated between the end of the $14^{\text {th }}$ century and the first half of the $15^{\text {th }}$ century and differently linked to Raimondo or Giovanni Antonio. Even though not so many years passed between the governments of the father and the son, their patronages were really dissimilar: the first was devoted to the tradition of Romanesque art, whereas the second focused on a language receptive to the International Gothic. This study wants to endorse the figure of Giovanni Antonio as commissioner of the tower and highlights the political importance of this piece of art declaring the power of the family in a territory at the borders of the Kingdom of Naples.

Keywords: Apulia; Orsini del Balzo; Soleto; Guglia; International Gothic; Gothic architecture; Gothic sculpture; Galatina, St. Caterina d'Alessandria.

Название статьи. У пределов Неаполитанского королевства. Гулья и князья Таранто Орсини дель Бальцо в Солето.

Сведения об авторе. Поллини Джулия - аспирант. Римский университет Сапиенца, Пьяццале Альдо Моро 5, 00185 Рим, Италия. giulia.pollini@uniroma1.it

Аннотация. Княжество Таранто, основанное в эпоху норманнского господства, было своего рода «спутником» Королевства Апулии и Сицилии, переходившего от императоров Священной римской империи к анжуйской династии. Князья Таранто находились под внешним наблюдением и избирались из местных правящих семейств для усиления контроля над территорией и более эффективного использования её выгодного географического положения, в частности торговых путей, ведущих через Адриатику на Восток. Особняком в длинном списке правителей Таранто стоят представители семьи Орсини дель Бальцо - Раймондо (ум. 1406) и его сын Джованни Антонио (ум. 1463), стремившиеся укрепить свои владения с целью достичь большей независимости от королевской власти. К этому периоду, начавшемуся в 1399 г. избранием Раймондо Орсини дель Бальцо князем Таранто, относится расцвет нескольких художественных центров в небольших городах княжества. Примером может служить базилика Святой Екатерины в Галатине близ Лечче, основанная Раймондо как семейная усыпальница и украшенная хорошо известным фресковым циклом начала XV в.

Небольшой город Солето, отделённый несколькими километрами от Галатины, приобрёл новое значение при Орсини дель Бальцо и стал контролировать значительную территорию. Представители княжеского рода возводят здесь ряд построек, самая значительная из них — так называемая гулья примыкающая к фасаду церкви Мария-Сантиссима-Ассунта башня высотой около 45 м, украшенная скульптурой и гербами.

Исследование посвящено анализу этой постройки, датируемой концом XIV - первой половиной $\mathrm{XV}$ в. и связываемой как с Раймондо, так и с Джованни Антонио. Несмотря на небольшой временной разрыв, постройки, возведённые по заказам отца, резко отличаются от заказов сына: первый был приверженцем романской традиции, второй предпочитал архитектурный язык интернациональной готики. В статье бприведены аргументы в пользу идентификации Джованни Антонио как заказчика башни и проведён анализ политического значения этой постройки, утверждающей власть княжеской семьи на территории, граничащей с Неаполитанским королевством.

Ключевые слова: Апулия; Орсини дель Бальцо; Солето; гулья; интернациональная готика; готическая скульптура; Галатина; св. Екатерина Александрийская. 


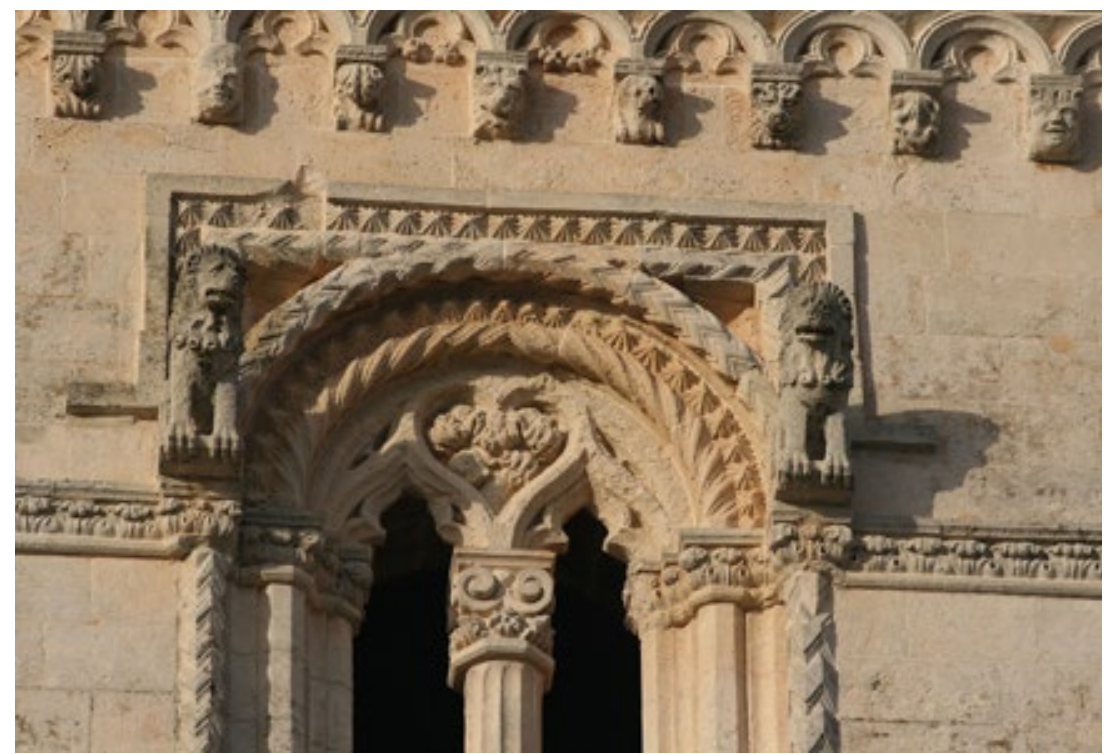

III. 97. Double-arched window, third story, south side, Guglia. $15^{\text {th }}$ century. Soleto. Photo by G. Pollini

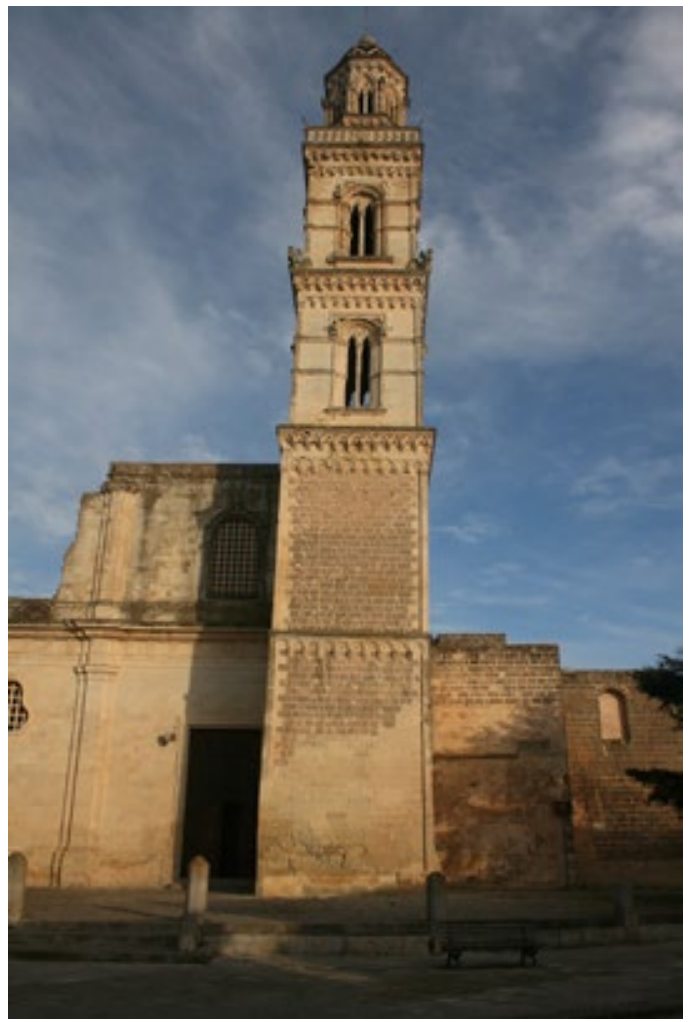

IIl. 98. Panoramic view, Guglia. $15^{\text {th }}$ century. Soleto. Photo by G. Pollini 


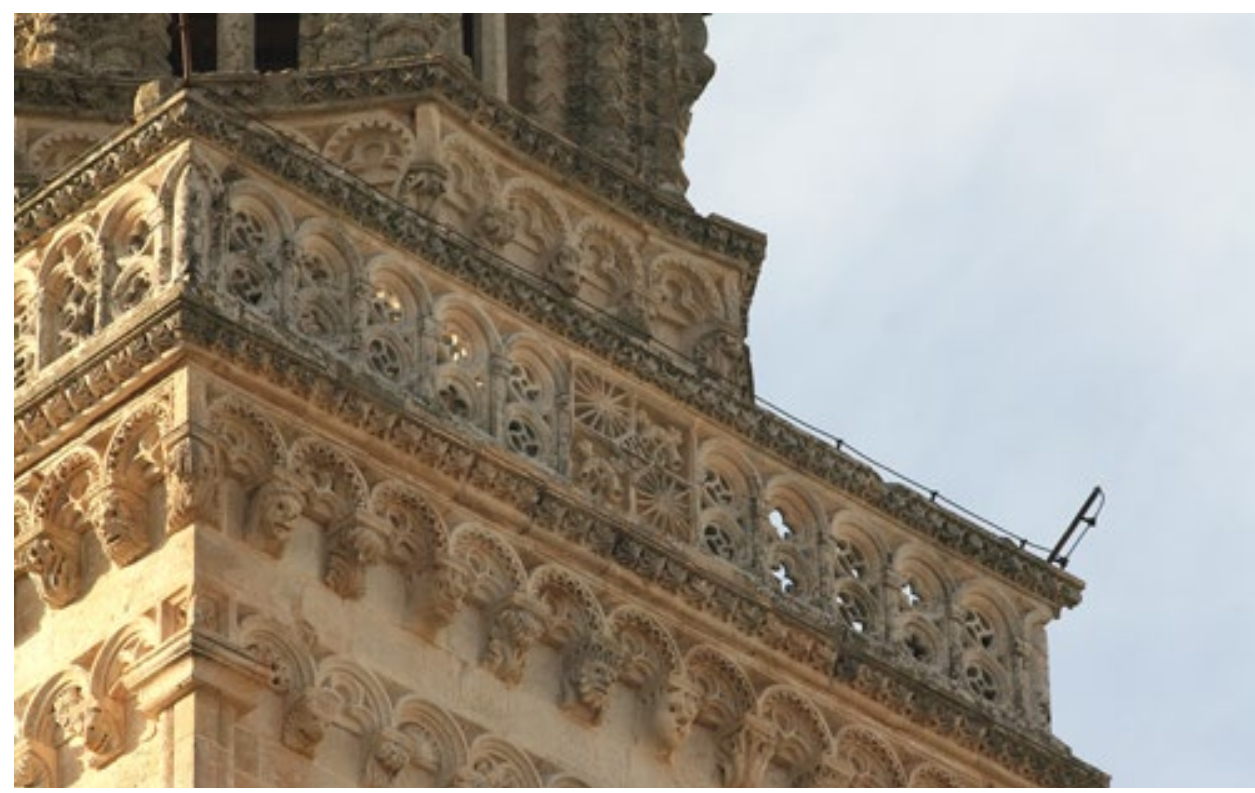

III. 99. Insignia of Orsini del Balzo, balustrade, east side, Guglia. $15^{\text {th }}$ century. Soleto. Photo by G. Pollini

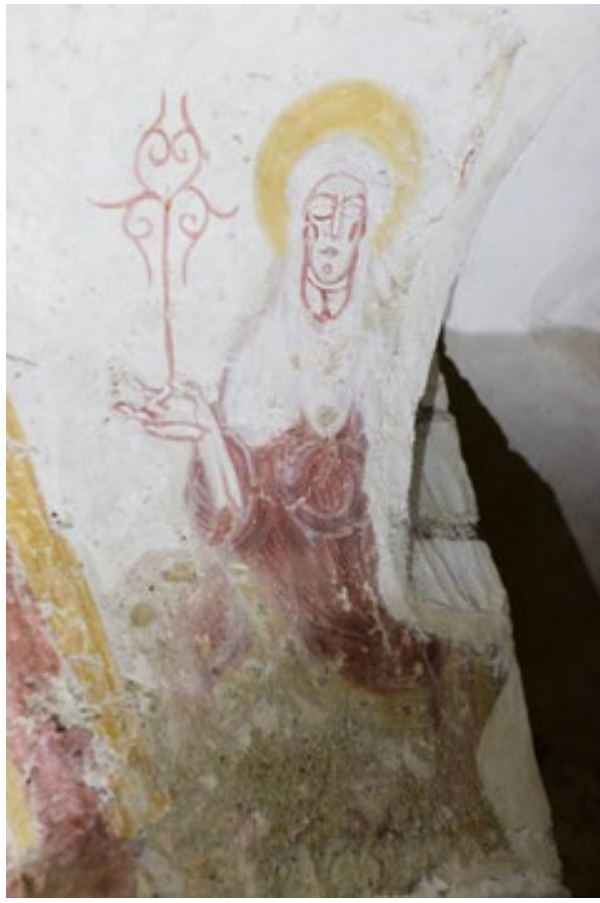

Илл. 100. Женский образ. Северный свод первой травеи. Середина XII в. Фреска. Крипта церкви Св. Николая в Таване, Франция. Фото Е. В. Рикоты

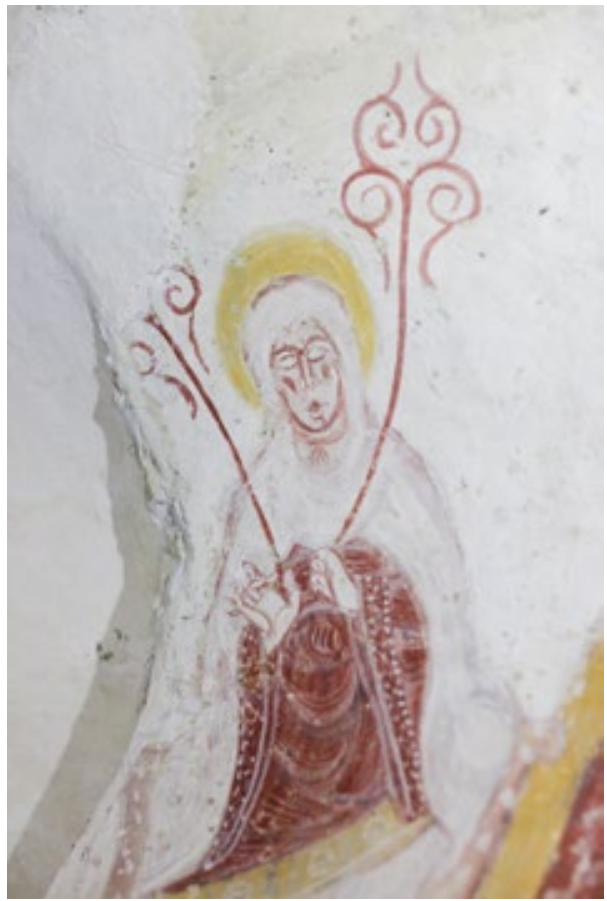

Илл. 101. Женский образ. Южный свод первой травеи. Середина XII в. Фреска. Крипта церкви Св. Николая в Таване, Франция. Фото Е. В. Рикоты 